\title{
Russkiy Mir: The Geopolitics of Russian Compatriots Abroad
}

\author{
Dr. MORITZ PIEPER \\ m.a.pieper@salford.ac.uk \\ +44 (0)1612954723 \\ University of Salford \\ Crescent House, Room 200a \\ M5 4WT Salford, United Kingdom
}

\begin{abstract}
This paper argues that the instrumental reference to Russian 'compatriots' in Georgia in 2008 and Ukraine in 2014 served as a discursive framing to justify contradictions in Russian approaches to state sovereignty to an international audience. Contrary to teleological readings of Russian foreign policy, however, the paper argues that while Russian diaspora policies have been tapped into, the iterative and partially contradictory development thereof on a governmental level suggests that these were not the blueprint for a revisionist foreign policy by design. It contextualizes the evolution of Russian diaspora policies against the background of the evolution of the wider 'Russian World' conception and shows how the discourse about the protection of 'compatriots' was contextual and has translated into geopolitical boundary-making at a time when relations between Russia and the West deteriorated.
\end{abstract}

Keywords: Sovereignty, Russian foreign policy, Boundary-making, Territory, diaspora identity, Security

\section{Introduction}

After the collapse of the Soviet Union, 25 million Russians suddenly lived abroad, outside of the new state borders of the Russian federation. How the Russian government should deal with these citizens became a subject of domestic debate within Russia and provoked a stream 
of scholarly studies on the subject (Aasland 1996; Kolstø 1993, 1995, 2001; Zevelev 1996, 2001; Melvin 1995, 1998; Zevelev 1996, 1998; Shevel 2012). Speculations that these new Russian diasporas might form political opposition groups in their new home states, become advocates for irredentist territorial claims, or 'vote with their feet' and emigrate to the Russian federation fueled the demand for new policies towards these Russians abroad (Heleniak 2004, 99). ${ }^{1}$ Policy responses ranged from Russian protests over new language and citizenship laws in the newly-independent neighbouring states (notably Estonia and Latvia) ${ }^{2}$ to new legislation in Russia aimed at defining ethnic and linguistic benchmarks for 'Russianness'. Yet, despite speculation to the contrary (Kolstø 1993; Laitin 1995), the Russian government during the 1990s did not devise transnational policies to influence Russians abroad in ways that would constitute an unlawful interference in the domestic affairs of other sovereign states. The latter is a principle in public international law explicitly underlined in Russia's Foreign Policy Concept (2016) and continuously referred to by Russian officials.

Russia's position on 'state sovereignty' was called into question with the outbreak of war in Georgia in 2008 in which Russia's claims to 'protect' Russians abroad have been translated into a foreign policy objective that justified the use of hard military means. The protection of 'compatriots' in the Georgian breakaway provinces South Ossetia and Abkhazia featured prominently in Russia's rhetoric to justify a 'rescue mission' for allegedly humanitarian reasons. A similar argument about the need to protect 'compatriots', this time around with an emphasis on Russian speakers abroad, was used again six years later to justify the annexation of Crimea in March 2014. This presents us with a puzzle that this paper posits to address: Russia's use of its diasporas within a wider 'Russian world' as a means for geopolitical ends (and which observers have called territorial revisionism) breaches the principle of non-interference in domestic affairs of other states that Russia's elite discourse continues to make reference to. Ruth Deyermond (2016) has theorized on a dual approach to sovereignty that Russia applies: a 'post-Soviet' approach for its neighborhood where 
sovereignty is contingent, and a 'Westphalian' model for states beyond its neighborhood, and it will be analysed here how diaspora arguments were put forward to smooth over such a contradiction in public diplomacy. Observed discrepancies between geopolitical strategies, the discursive framing of foreign policies, and international agreements, however, are not unique to Russia. Stephen Krasner has famously called sovereignty 'organized hypocrisy' (1999), arguing that the frequent violation of longstanding norms has been an enduring feature of international relations. The projection of a particular narrative is part and parcel of public diplomacy. The aim is to make an intended audience receptive to one's own foreign policy objectives. States employ 'strategic narratives' to favorably influence other actors in international affairs (Miskimmon, O’Loughlin \& Roselle 2013).

Against this backdrop, it would be an analytical fallacy to assume that Russian foreign policy is inherently more 'revisionist' than that of other governments. The fine line between diplomacy and public relations is about the distinction between communicating policies and selling them. This is not unique to Russian foreign policy, but the terms may differ. Saari (2014) has found a distinction between a general 'obshechestvennaya diplomatiya' (public diplomacy) and Russia's public diplomacy geared towards its post-Soviet neighborhood labeled 'gumanitarnoe sotrudnichestvo' (humanitarian cooperation') (54). 'Humanitarian cooperation', as misleading as the term is in a Western understanding, is understood as the umbrella term for Russia's policies towards its 'compatriots' abroad. This paper shows how the recurrence to such a 'humanitarian' aspect was used in Georgia in 2008 and Ukraine in 2014.

Blending a geopolitical analysis of the two conflicts mentioned with a conceptual discussion of the policy relevance of 'Russian diasporas', the paper thus conceptualizes the political instrumentalisation of Russian 'compatriots' abroad within the literature at the interstice of diaspora studies and conflict analysis. Case studies of the identities of Russian diasporas have been conducted elsewhere, in particular with a view to places where large 
populations of Russians are to be found: Estonia (Kallas 2016; Smith 1999; Smith \& Wilson 1997; Lauristin \& Heidmets 2003; Korts 2009), Belarus (Brüggeman 2014); Latvia (Smith 1999), Ukraine and Kazhastan (King \& Melvin 2000); and Central Asia (Kosmarskaya 2011; Ziegler 2006; Grigas 2016). Likewise, analyses of the evolution of the 'Russian World' concept have been conducted before (Bremer 2015; Gasimov 2012; Jilge 2014; Kudors 2014; O’Loughin, Toal \& Kolosov 2016; Shchedrovitskii 2000; Tishkov 2008; Toal 2017; Zabirko 2015; Zevelev 2014). Charles Clover (2016) has traced the Kremlin's circumstantial embrace of Alexander Dugin's 'Eurasianist' philosophy as well as that of other more nationalist movements to frame controversial foreign policies, from Russia's second Chechen war to the 2008 war with Georgia to the 2014 annexation of Crimea (249-332). In a recent study, Mikhail Suslov (2018) has usefully explored the nexus between political discourses on the 'Russian World' concept and the logic of 'spheres of influences', tracing the non-linear iterations of a concept employed by a government in search of its international identity. However, the literature on diaspora identity and on 'Russian World' conceptualisations have not been brought together yet in an attempt to substantiate the debate about the instrumentalisation of Russian diasporas in conflict situations against the background of Russian approaches to state sovereignty.

On a conceptual level, this paper therefore adds to the literature on diasporas with a process-tracing analysis of the development of Russian 'compatriot' policies with a particular view to its politically instrumental nature in Georgia in 2008 and in Ukraine in 2014. The timely dimension to this subject also lends it substantial empirical significance that adds to our understanding of diaspora-related Russian foreign policy-making. Given the investigation of a link between geopolitics and identity narratives, such a purposive sampling is justified as a case selection technique. The aim here is not to provide a comparative classification of the diverse Russian diasporas abroad, nor to speculate on likely future policies in Russia's neighborhood where the articulation of compatriot policies has not been translated into 
military policies. Neither are other policy instruments discussed that have been associated with Russian compatriot policies elsewhere (politicization of history, 'destabilisation' policies that include the use of 'hybrid' and cyber warfare, or media policies). ${ }^{3}$

Instead, the analysis that follows focuses on the link between the evolution of the 'Russian World' conception and Russian compatriot policies, and the use of these to justify geopolitical boundary-making. Methodologically, the political use of Russian diasporas in conflict situations will be analysed by way of qualitative document analysis of independent commissioned reports, primary Russian policy documents and the scholarly literature. The angle taken is that of a foreign policy analysis, where the rhetoric used by the Russian government will be embedded in a process-tracing analysis of the evolution of state policies towards Russians residing abroad (Beach \& Pedersen 2013, 3).

The argument proceeds in three sections. A first section provides a brief conceptual overview of Russians abroad, and distinguishes between ethnic, linguistic, and other indicators used to classify Russians abroad as part of a 'diaspora'. This section draws on the literature of diaspora studies and provides the conceptual foundation for this paper. A second section briefly outlines the evolution of Russian diaspora policies, and how Russians abroad became 'compatriots' in Russian governmental discourse during the Yeltsin and Putin administrations. A third section analyses how a discourse on Russian diasporas translated into military policies in two conflict situations: The war in Georgia in 2008, and the annexation of Crimea in 2014. It will be argued that these two conflicts reveal implicit contradictions in Russian public diplomacy and Russian approaches to 'state sovereignty'. The political costs involved, however, were seen as being outweighed by strategic benefits.

\section{Russians abroad: A conceptual overview}

Defining diasporas has been notoriously difficult. King and Melvin (1999/2000) lament the 'semantic malleability of the label "diaspora"" (113), and Brubaker (2005) even writes that 
the term 'diaspora' has been 'stretched to the point of uselessness' (3). Most definitions, Brubaker continues, revolve around three main criteria: Dispersion (of a diaspora across state borders), 'homeland orientation' (broadly defined as a certain collective memory and emotional attachment to the 'homeland'), and 'boundary-maintenance', which he defines as the 'preservation of a distinctive identity vis-à-vis a host society' (6). ${ }^{4}$ These criteria have been emphasized in most other seminal accounts of diasporas (e.g. Armstrong 1976; Safran 1991, 83; Cohen 1997, 24; Tölöyan 1996, 14).

Senses of belonging and identity, however, can overlap. Brah (1996, 208-9) therefore writes of a 'diaspora space' that is characterized by the contestedness of belonging and Otherness, and Faist (1998) writes in this context of a 'transnational social space' (216). Senses of belonging can be the result of 'transethnic and transborder linguistic categories' (Brubaker 2005, 3). This can create frictions between host and home countries, as it opens up the possibility for advocacy by foreign governments on behalf of their ethnic brethren abroad at the expense of immigration and assimilation policies in host societies (Moore \& Davis 1998). 'Diasporisation' has therefore come to be understood as the 'ethnification of transnational connections' (Kallas 2016, 2). Such a reading has given rise to analyses of the usage of diasporas for foreign policy goals on the part of their 'homeland' states. For instance, studies have analysed the links between diaspora politics and the potential for transnational mobilization of Russians abroad in the post-Soviet environment (Aasland 1996; Kolstø 1993, 1995, 2001; Zevelev 1996; Melvin 1995, 1998; Zevelev 1996, 1998; Shevel 2012). Yet, besides the two cases discussed in a later part in this paper, there are only few examples of home states 'protecting' their diasporas militarily. Hitler's claim to 'protect' Volksdeutsche residing outside of Germany's current borders (by expanding these borders) is the most notorious example. Turkey's invasion of Cyprus in 1974 is cited as another such example where the argument for military intervention as a protective measure has been employed (King and Melvin: 1999/2000, 116). The role of Serbia in the Bosnian war in the 1990s is 
more complex and involved ethnoterritorial claims and the mobilization of paramilitary and transnational actors. Constraints on the ability of 'ethnic patrons' to either mobilize diasporas or employ the argument about diaspora protection in foreign policy include a 'sense of attachment to the homeland among the dispersed ethnic group, competing foreign policy priorities within the kin state, and the economic resources that the kin state can wield to reach out to its diaspora' (King and Melvin, 1999/2000, 110). 'Diaspora politics', King and Melvin (1999/2000) continue, 'is in this sense more an antidote to irredentism than a catalyst for territorial conflict' (136). The Russian diaspora is no exception, and is far from a homogenized entity (Smith \& Wilson 1997, 846).

With a view to Russian speakers abroad, these definitions already indicate difficulties with the application of the term: Russian speakers can be well integrated into their host societies, so neither the criteria of 'boundary-maintenance' nor of 'homeland orientation' necessarily needs to apply. Russians abroad do not need to have a troubled relationship with their host society. Language, identity, ethnicity and citizenship, in other words, do not correlate in a straightforward way. Official Russian policy documents refer to the Russian diaspora as 'ethnic Russians' (russkie), 'Russian speakers' (russkoiazychne), 'cultural Russians' (rossiiane), 'compatriots' (sootechestvenniki), 'countrymen abroad' (zarubezhnye sootechestvenniki), or 'fellow tribesmen' (soplemenniki). The seemingly semantic fluidity reflects policy uncertainty over who is to be included, and by what criteria. As will be seen in the next section, Russia's government has come to prefer the term 'compatriots' as a broader catch-all label that includes Russian speakers, ethnic Russians, and those with cultural ties with their 'homeland' and a wider 'Russian World' (Russian foreign ministry 2006). Rather than enticing Russians abroad to embrace revisionist policies or actively tie them into compatriot policies, 'all ethnic groups with a cultural and historic link to Russia were "diasporized" through a growing reference to the Russian-speaking minorities in the former republics as “compatriots” (sootechestvenniki)', Pilkington \& Flynn $(2001,11)$ write. 
Against the background of this (deliberate) semantic ambiguity, the remainder of this paper will shed light on the reference to 'compatriots' in the formation of Russian diaspora policies in a first part, while a second part discusses references to Russian 'compatriots' in conflict situations as an illustration of the translation of Russian compatriot policies into operational security policies.

\section{The perception of Russian compatriots in Russian foreign policy}

After the fall of the Soviet Union, the fault line, Brubaker (2000) writes, ran 'between the nationalizing nationalisms of Soviet successor states and the homeland nationalism of Russia' (7). While Turkmenistan and Tajikistan were the only state to grant dual citizenship (Heleniak 2004, 108), all other post-Soviet states granted only one citizenship with the goal of building nation and society on a civic (as opposed to an ethnic) basis. Perhaps unsurprisingly, these newly independent countries developed policies that would set them apart from Russian influence in what Tishkov (2008) calls the 'anti-Russian component of post-Soviet nationalisms' (31).

Policy responses of the Russian government initially were mixed. Russia did not encourage a mass return of its 'beached diaspora' (Laitin 1995), but rather engaged in advocacy on the Russian diaspora's behalf to push for the granting of dual citizenship (Heleniak 2004, 111). This often went hand in hand with critiques of non-Russian states' language laws. In 1992, the Russian government criticized Estonia and Latvia for disadvantaging Russian language-speakers (Hill and Gaddy 2013, 34-35). Both states had linked the granting of citizenship to residence and language requirements (Grigas 2016, 66). It was around this time that influential voices within Russia began to realize the potential of Russian diasporas as leverage tools in foreign policy. In late 1992, Sergei Karaganov's name became attached to the idea that Moscow should see ethnic Russians residing abroad as a tool to gain influence in these regions (Smith et al. 2002, 161). ${ }^{5}$ Publicly emphasizing their right to 
speak Russian, so an often-repeated reading went, would serve to keep the diaspora's loyalty to Moscow and function as an entry point into the formulation of societal and economic policies of their new home states (Mackinnon 2014; Melvin 1995, 10). ${ }^{6}$

Yet, for all the myth-building surrounding the 'Karaganov doctrine', it has to be kept in mind that domestic debates within Russia were more complex and included a plethora of often conflicting voices (O’Loughlin, Toal and Kolosov 2016, 746-753; Zevelev 2001). Nationalist and communist political forces within Russia criticized the Russian leadership for what they perceived as a lack of interest in the fate of their co-ethnics abroad. Influential politicians like Anatoly Chubais were arguing that the Kremlin should promote and defend the rights of Russian-speakers in Russia's 'near abroad' (blizhneye zarubezhye) (Chubais 2003). Only gradually, the Russian government took an interest in Russians and Russian speakers abroad.

At the UN level, the Russian government started to couch its policies in the "near abroad' in humanitarian terms that revolved around concerns for cultural, linguistic, economic, educational and political rights of Russians abroad (Smith 1999, 508). This discourse reached a new level that would lay the basis for later policy arguments when in September 1993 at the UN General Assembly, Foreign Minister Andrei Kozyrev declared Russia's 'special responsibility' for protecting Russian language speakers (including in Transnistria and the Baltic states). He also demanded the UN grant Russia primacy in future peacekeeping missions in the former Soviet republics (Hill \& Gaddy 2013, 34-35). The Baltics would have none of that. 'Russia thought that they could administer our independence post-1991', an Estonian foreign ministry official told the author in an interview. ${ }^{7}$ Soviet forces had to withdraw, which they did by 1994. Russian troops, however, stayed in Georgia and Azerbaijan (Fischer 2016, 15). Additional Russian peace-keeping troops in Transnistria, Abkhazia, and South Ossetia began to cement Russian influence over new territorial delimitations. 
On an institutional level, the role of Russian language groups abroad was given more attention only gradually. It took until 2004 for an Agency for Compatriots Living Abroad to be established as a division of the Russian foreign ministry. The Department for Work with Compatriots Abroad at the foreign ministry was then established by presidential decree in November 2005 (Ziegler 2006, 121). While migration policy is a policy domain that falls within the competence of the interior ministry, the foreign ministry had thus been tasked with policy coordination to do with Russian diasporas (Russian foreign ministry 2017). The Putin administration had come to the realization by the mid-2000s that the presence of large diaspora populations in many of the non-Russian states in the post-Soviet neighborhood was going to remain a permanent feature of Russia's neighborhood policies. ${ }^{8}$ The 2008 Russian Foreign Policy Concept commits the government to protect compatriots abroad, and identifies 'discrimination and the suppression of the rights, freedoms and legitimate interests of the citizens of the Russian Federation in foreign states' as main threats to not only Russian compatriots, but also Russian security interests (Kremlin 2008; Hedenskog and Larsson 2007, 33). Kristina Kallas (2016) thus writes: "The interchangeable usage of "compatriot protection" and "national interest protection" raised questions about the role compatriots might play also in serving "national interests"" (emphasis in the original, 6).

After 2006, compatriot policies reached a new level of institutional consolidation. The foreign ministry set up a 'department for relations with compatriots abroad', and Coordination Councils of Russian diasporas were set up abroad to work closely with the Russian foreign ministry (Brüggemann 2014, 92). ${ }^{9}$ Moreover, state organisations like Roszarubezhtsentr (Center for Russians Abroad) served to support Russian-speakers residing abroad. Roszarubezhtsentr was turned into the new agency Rossotrudnichestvo (Federal Agency for the Commonwealth of Independent States, Compatriots Living Abroad and International Humanitarian Cooperation) in September 2008. ${ }^{10}$ But reaching out to Russian language diasporas was not only confined to government ministries. ${ }^{11}$ The use of the Russian language 
as a politically unifying instrument has been a core purpose of the foundation 'Russkiy Mir'. This foundation, founded in 2007 by a presidential decree as a joint project of the Russian foreign ministry and the ministry of education and Science, promotes the Russian language and culture abroad, and thus 'reconnects the Russian community abroad with their homeland, forging new and stronger links through cultural and social programs, exchanges and assistance in relocation', as the Foundation's mission statement reads on its website (Russkiy Mir 2017).

Language here is linked to the preservation of a particular cultural community that sets the 'Russian World' apart from other, e.g. Western cultures, and it is at this point that a conceptual framework began to emerge that serves to bind together diaspora identity politics and cultural diplomacy. The focus on the link between language and culture harks back to the russkiy mir debates of the 19th century, in which the 'Russian World' became defined as the slavophile antipode to the European orientation of the Zapadniki (Gasimov 2012, 71). This rediscovery was promoted by an eclectic range of movements and actors, from Alexander Dugin's obscure neo-Eurasianism (Mathyl 2002) ${ }^{12}$ to the Russian Orthodox Church (ROC). ${ }^{13}$ The publication of Pyotr Shchedrovitskiy's 'Russkiy Mir and the Transnational Russian' ('Russkiy Mir I Transnatsionalnoje russkoye') in 2000 is said to have marked the explicit politicization of the term: According to his conception, the 'Russian World' is made up of diverse language diasporas and transnational communities that can be used by the Russian state to gain access to financial and economic resources (Zabirko 2015, 5). ${ }^{14}$ In Shchedrovitskiy's approach, Russians abroad not only form a linguistic community, but constitute a 'geo-cultural' leverage power for the Russian government (Tishkov 2008, 5). Andis Kudors (2014) summarizes the 'Russian World' conception as a 'supranational structure that consists of Russia, the Russian diaspora living abroad and other so-called Russian-speaking communities, which consider Russia as their cultural and spiritual center'.

The transnational character of the 'Russian World' concept and the post-Soviet 
narrative of 'Russia as a divided nation' (Laruelle 2015b, 89) can therefore give the foundation with the same name an implicit political connotation (Petro 2015). Russian experts, however, emphasise that the purpose of 'Russkiy Mir' is not different from that of other cultural institutes such as the British Council, the German Goethe Institute or the French Francophonie. According to this view, the Foundation's focus on the Russian language is inseparable from a wider 'soft power' mission to further Russia's influence to the extent that the promotion of language and culture is part and parcel of a country's foreign cultural policy. ${ }^{15}$ Tellingly, a Russkiy Mir representative recounts in an interview with the author how Rossotrudnichestvo came up with the idea of disseminating Crimea-related propaganda material in 2014, but that Russkiy Mir would have none of that. 'When the government was suddenly using the term [Russkiy Mir] in the Ukraine crisis, we were taken by surprise', he stated. ${ }^{16}$ The foundation 'Russkiy Mir' has to be understood as a government-funded initiative to promote not only the use of the Russian language (a 'transborder linguistic' category, Brubaker 2005: 3), but as a medium of Russian foreign (cultural) policy to create transnational links between 'the homeland' and Russian language-speakers abroad (Saari 2014, 61; Zhurzhenko 2014; Laruelle 2015b; Kallas 2016, 8; Ryazanova-Clarke 2014). It serves to 'diasporize' dispersed Russians abroad by nurturing a sense of identity and belonging, by creating what Faist $(1998,216)$ calls a 'transnational social space'. As a wider political term, however, the 'Russian World' concept has acquired a new political connotation in the context of the 2008 Russo-Georgian war and the 2014 'Ukraine crisis'. The 'Russian World' concept had become a unifying conceptual umbrella that would link diaspora policies to an official level of cultural outreach diplomacy, but its articulation for geopolitical ambitions that would lay bare contradictions in Russia's conception of state sovereignty only became an official talking point at a time of new tensions between Russia and the West. The instrumentalisation of Russian co-ethnics and language speakers abroad has meant the translation of the idea of a politico-cultural unification of the 'Russian World' into a 
justification for military interventions, and it is to this aspect that the next section now turns its attention.

\section{Russian intervention in Georgia and the manufacturing of Russian diasporas}

Much has been made of the 'Karaganov doctrine' of 1992 as an ominous forerunner of events in 2008. As Sergei Karaganov told the author in Moscow, however, his 'doctrine' did not advocate for the military protection of Russians abroad. Its conceptual origins, as analysed above, lay in attempting to grapple with the post-Soviet legacy in addressing diaspora politics primarily by way of citizenship and language policies. When in August 2008 the Russian army invaded the sovereign territory of Georgia proper in response to Georgian military operations in South Ossetia, Russia's stated need to 'protect' Russians abroad was translated into operational military policies. Russian diasporas came to be 'weaponised'. ${ }^{17}$

For the argument here about Russian compatriot protection, the coming into being of that particular diaspora is relevant: Before the invasion of Russian troops and the resulting Georgian-Russian war, Russian passports had been handed out on a large scale in what has been called a policy of 'passportization' (Fischer 2016, 21; Grigas 2016). The Tagliavini commission, instituted as an independent fact-finding mission on the conflict in Georgia, held that the handing out of passports on a massive scale in Georgia prior to the war fulfilled criteria of extraterritorial collective naturalization and was therefore in breach of international law (IIFFMCG 2009, 155-178). Already in 2002, Russia had started a process of simplifying procedures for residents of de facto states to acquire Russian passports (IIFFMCG 2009, 18; Littlefield 2009; Mühlfried 2010). Grigas $(2016$, 42) notes that Russian ethnicity was not a prerequisite for passportization. The thus newly-naturalized Russians justified the Kremlin's justification for its intervention of having to protect ethnic Russians from 'Georgian aggression' in the break-away Georgian provinces of South Ossetia and Abkhazia. While in most cases, Russia did not have to force Abkhaz and South Ossetians to adopt Russian 
citizenship as it came with tangible travel, work and pension benefits, (Artman 2013, 690; see also Toal 2017, 140;), ${ }^{18}$ Russia's passport policies in Abkhazia and South Ossetia gave it an empirical basis for the argument that the residents in these entities were 'compatriots' - an 'epistemic linkage between population and territory' as Artman $(2013,694)$ calls it. He further argues that 'passportisation' has created 'exceptional spaces' within Georgia 'where the norms of international law and the modern state sytem were effectively suspended' (682). It had created Russian 'spaces' within Georgian de jure territory even before the fighting in South Ossetia began. Such a 'manufacture of nationals' (Green 2010, 72) redraws the territorial, legal, and biopolitical map. As Artman (2013) shows, it undermined Georgian sovereignty before any military intervention did.

The claim that passportization was merely intended to 'help' de facto state residents also ignores the geopolitical context in which passportization occurred. An overview of Russia's motivations behind its military operations in 2008 and 2014 is beyond the scope of this paper. This has been thoroughly analysed elsewhere (Stent 2014; Toal 2017). IntraOssetian and Georgian domestic politics under Mikheil Saakashvili after the 2003 'Rose Revolution' played as much a role as contextual factors such as Russian concerns over geopolitics following the 2008 NATO Bucharest summit (which had failed to grant Georgia and Ukraine a Membership Action Plan, but did add that 'these countries will become members of NATO'). A revisionist Georgian government was pushing back against an increasingly assertive Russia (Artman 2013, 689; Toal 2017, 166-190). And on a structural level, Putin had reportedly made it clear that Georgia was paying the price for the recognition of an independent Kosovo by most Western governments in 2008 (in: Asmus 2010, 106). Besides intra-Georgian politics, the negative atmospherics between Putin and Saakashvili and the particulars of Georgian-Russian relations, the 2008 war therefore also had instrumental value for broader Russian-Western relations. Different readings of Russian foreign policy in this episode lie at the heart of heated debates about conceptions of sovereignty, but also 
expose the dilemma of regressive causality. One either subscribes to a reading that biopolitical arguments (compatriot policies) were merely put forward by a Russian government to justify territorial shifts, or to a reading that emphasizes revisions in the political status quo which promised potential revisions in the territorial status quo as well on the part of other powers which have triggered Russian interventions. The former reading focuses on a Russian government reevaluating its fading regional hegemony, bent on dominating its neighbors, the latter on actions on the part of the Georgian government, on NATO expansion plans, and on a perceived Western 'encirclement' of Russia. ${ }^{19}$ The US and the EU, according to the latter perception, had attempted to pull Georgia and Ukraine into the West's orbit with its alleged complicity in the countries' 'color revolutions' of 2003 and 2004 (the latter coinciding with the 2004 NATO enlargement wave). The West, in contrast, seized on the narrative of 'captive nations' in Central and Eastern Europe following the end of the Cold War and argued that the finalite of regional integration projects was the eventual 'unification' of the European continent. Without an appreciation of these two clashing geopolitical meta-narratives, we cannot understand the dynamics of a 'politicisation' of diasporas in public discourse.

What is thus relevant here for an investigation into the link between such military operations and 'compatriot' policies is that the more complex empirics of the respective conflicts were framed in a way that would justify Russian intervention as a 'rescue mission' of co-ethnics and compatriots against the invoked twin threats of 'fascism' and 'genocide' in neighboring sovereign countries. Russia presented its policies as reactions to a provocative and reckless Georgian leadership and as a necessary corrective to artificial borders of nominally independent states that were hiding more complex ethnoterritorial and sociopolitical realities (Medvedev 2008a). Russia's UN ambassador Churkin invoked its 'inherent right to self-defense enshrined in Article 51' of the UN Charter (Churkin 2008), and President Medvedev made recourse to a discourse that presented Russia as a patron state for 
its citizens, whether they are residing in Russia or abroad: 'In accordance with the Constitution and the federal laws, as President of the Russian Federation it is my duty to protect the lives and dignity of Russian citizens wherever they may be' (ibid.). The reference to 'Russian citizens' was not irrelevant during the intervention in the de facto states, given that Abkhaz do not consider themselves 'Russian' in any meaningful way apart from citizenship status (Petersen 2017, 98-99).

Four days later, Medvedev took the step to call the actions of the Georgian forces 'genocide' (Medvedev 2008b). Similarly, Russia's UN ambassador Vitaly Churkin and Russia's foreign minister talked of 'genocide' when referring to Georgian military actions in South Ossetia - an instrumental language that implicitly justified Russia's intervention for humanitarian reasons (UNSC 2008, 8; Fawn and Nalbandov 2014, 73). The Russian government thereby started to adopt a discourse emanating from Ossetia, and formulated a responsibility to protect Russian passport-holders from alleged genocide planned and carried out by the government in Tbilisi (Karagiannis 2014, 405; Allison 2008; IIFFMCG 2009). It also was quick to compare the situation with NATO's intervention in Kosovo in 1999 in an attempt to end atrocities against ethnic Albanians. ${ }^{20}$ The Kosovo 'precedent' identified by the Russian government indicated that the Kremlin began to re-frame its Georgian operation as a humanitarian intervention, relying on a similar language that the West had used in 1999 with the difference that 'humanitarian cooperation', as noted above, here referred to the protection of Russian 'compatriots' abroad. Russia had begun to conceptualise its very own 'responsibility to protect' minorities abroad despite its previous resistance to the doctrine (Toal 2017, 185). Interestingly, however, Russia's deputy foreign minister said on 13 August 2008 that $[\ldots]$ ' Russian peacekeepers will stay there and will be protecting the life, honor and dignity of the multinational population of these republics' (Russian foreign ministry 2008, emphasis added). This reference to ethno-nationality, rather than citizenship-nationality, calls into question the political and symbolic value of what 'passportization' has achieved in the 
two de facto states. Russia has helped to create a 'transnational social space' (Faist 1998, 216) characteristic of diasporas, but a 'homeland orientation' (Brubaker 2000, 6) has to grow organically. It is also important to note that the Kremlin did not adopt the position of Russian nationalists at the time favoring annexation of de facto states (even though it took the decision to recognize Abkhazia and South Ossetia as independent states on 26 August 2008).

\section{Crimea and the Donbas: Between absorption and reluctant protection}

Russia's annexation of Crimea in 2014 as a reaction to a governance crisis in Ukraine triggered over Kiev's derailed association agreement with the European Union (EU) and Ukrainian President Viktor Yanukovich's eventual flight to Russia was based on similar arguments to the ones presented in Georgia in 2008 pertaining to the need to protect compatriots (Ryazanova-Clarke 2015; Gaufman 2015), but focused much more on the Russian language argument, thus evoking a more emotive-cultural tie with the 'homeland'. Emphasizing the need to protect Russian passport-holders, as in Georgia's case, was not a prominent policy feature in Ukraine, because the need to protect 'compatriots' was based on the alleged linguistic discrimination of Russophones by the Ukrainian authorities. The new interim government in Kiev, in Putin's speeches, constituted a threat to Russian speakers and religious minorities in Ukraine, and especially in the east and Southeast, including Crimea (Hill and Gaddy 2013, 365). Russia was alleging that right-wing, nationalist forces in Kiev were suppressing ethnic Russians and Russian-speakers (Stewart 2017, 18; Toal 2017, 223226).

The (unsuccessful) attempt made by the Ukrainian parliament to repeal the status of Russian as an official language on 23 February 2014 was read as a further confirmation of these fears. Following a similar narrative to that in 2008 about a humanitarian responsibility of the Russian state, Russian-language speakers thus needed to be protected. ${ }^{21}$ Lara 
Ryazanova-Clarke (2015) writes that '[...] Russian speakers in Crimea and the East of Ukraine are categorized as belonging to the nation of the "Russian world" torn apart' (9), which she defines as 'linguistic weaponization' (9). In his historic address on the occasion of the annexation of Crimea, President Putin thus referred to the 'aspiration of the Russians, of historical Russia, to restore unity' (Putin 2014a) and compared Crimea's 'reunification' with Russia to the German reunification in 1989. On 17 April 2014, deliberately conflating Russians and Russian speakers, he further explained Russian actions as follows:

The most obvious risk was that the Russian speaking population was threatened and that the threats were absolutely specific and tangible. This is what made Crimean residents, the people who live there, think about their future and ask Russia for help. This is what guided our decision [...]. (Putin 2014b).

The invocation of that threat was inflated with a discourse on the 'fascist' nature of the illegitimate government in Kiev (Putin 2014a), which presented Russian actions as a protective reactionary measure. The annexation of Crimea was not only a far-reaching claim of extraterritorial authority in a context of Russian-Western tensions over questions of regional integration, but a breach of international law and the principles of territorial integrity enshrined in the UN Charta, the 1975 Helsinki Final Act, and the 1990 Paris Charta (see also Grant 2015; Geiss 2015). It was also a violation of the 1994 Budapest Memorandum, in which Russia had recognized 'the independence and sovereignty and the existing borders of Ukraine' in exchange for Ukraine's accession to the nuclear non-proliferation treaty as a means of denuclearizing its Soviet-inherited nuclear arsenal. ${ }^{22}$ With this, the Russian government violated a principle it repeatedly mentions as inviolable (Stewart 2017, 11).

The wider political implications of Russian military support for its compatriots abroad is that it lays bare the contradiction inherent in Russia's talk about non-interference and state sovereignty as inviolable principles of international law. Russian politicians have justified this 
contradiction with reference to past Western violations of state sovereignty, and have cited the Kosovo case as the precedent that has opened a dangerous Pandora's box on secessionism (Putin 2006). A discrepancy between discourse and behaviour is not an unsurprising finding in foreign policy analysis. The claim to protect populations divided by state borders, however, (Russia as a 'divided nation') raises legitimate concerns if combined with policies of territorial revisionism. International law and the conception of state sovereignty, so the outside impression, are seen as dispensable when clashing with Russian order conceptions in the post-Soviet space (see also Stewart 2017). Russia's neighborhood policy focus of 'gumanitarnoe sotrudnichestvo' (humanitarian cooperation'), in this reading, justifies a different approach towards the sovereignty of post-Soviet neighbors and Russia's use and instrumentalisation of its diaspora to reach its geopolitical objectives in this region. Ruth Deyermond (2016) writes in this context of a dual approach to sovereignty that Russia applies, and identifies a 'post-Soviet' approach for its neighborhood where sovereignty is contingent, and a 'Westphalian' model for everyone else outside of it. This is an assessment shared by Fiona Hill and Clifford Gaddy (2015), who argue that Putin's view of foreign affairs is conditioned by his perspective of US-Russian relations, and that he sees Russia as the only truly sovereign power surrounded by states with 'contingent sovereignty'. Even scholars that do not buy into this rather exclusionary logic acknowledge that Russia's discourse on sovereignty and territorial integrity, voiced in its official public diplomacy, has not been implemented consistently in Russian policies towards its neighbours (Sakwa 2017, 257; Sherr 2013). With the annexation of Crimea, Moscow illustrated that Ukrainian sovereignty was seen as negotiable. Seen in the context of the 'Russian World' conception as laid out above, the Russian state 'claimed' diasporas that were connected to their homeland on a linguistic and perhaps emotive dimension, but not necessarily on a political one. There is ample evidence that a belonging to an ethno-linguistic Russian diaspora does not automatically translate into pro-government sympathies for the Russian 'homeland' (Tishkov 
2008, 32-33; Smith 1999; Smith and Wilson 1997; Kosmarskaya 2011; Kallas 2016, 15; King \& Melvin 2015, 115; Heleniak 2004, 114; Kolstø 2010; Toal 2017, 268-273).

Yet, speculations that Russia's government might not consider the 'Russian World' to end at Russia's international borders were further nurtured when the term Novorossiya (New Russia) re-entered Russian public discourse at a time when tensions surrounding Russian interference in Ukraine were high (see also Jilge 2014; O’Loughlin, Toal and Kolosov 2017). The Russian government now re-discovered a term that had been used during Tsarist imperial times to emphasise the common heritage between Russia and Southeastern Ukraine under the administrative control of Russia, but which had never had fixed spatial delimitations. Novorossiya was a geopolitical imaginary. With this re-discovered discourse, the Russian government linked its Ukraine policies to a conception of the 'Russian World' (as analysed above) that is not confined to the borders of the Russian Federation (Lavrov 2014). ${ }^{23}$ This was a deliberate semantic ambiguity with political connotations. Russia's discourse on diaspora was now not only publicly linked to foreign relations with its immediate neighbors (this had been the case already in the 1990s, as shown above), but connected Russian-speakers or compatriots and the 'Russky Mir' concept with geopolitical policy goals. Appealing to a 'reunification' in line with the idea of a 'Russian World' to justify boundary-making and the redrawing of political maps might not mobilise diasporas, but it instrumentalises their presence politically.

The casual and rare official references to the 'Russian World' concept, Yuri Teper (2016) holds, point towards its utility as a 'fashionable catchphrase' (387). The abandonment of this discourse as the secessionist movement in Southeastern Ukraine was faltering in 2015 indicates that Putin's government was reluctant to encourage a risky geopolitical maneuver on the basis of ethnolinguistic arguments. Having deliberately conflated 'Russkiye' and Russian speakers in the case of Crimea, the Kremlin now appeared eager to keep at bay those nationalists calling for a further redrawing of the map in Eastern Ukraine. Russia's 'rebirth' 
was framed as a national, as opposed to an imperial one, as Teper $(2013,389)$ points out. In 2015, Lavrov stated in an interview that 'Novorossiya is a fairly vague term', and continued to make specific remarks on the 'Donetsk and Lugansk people's republics' (Lavorv 2015). The Kremlin ignored the appeal for Moscow to 'absorb' the self-proclaimed Donetsk Peoples Republic (Toal 2017, 265; Laruelle 2015a). And while the Russian Federation Council had passed a law facilitating the naturalization of Russian-speaking non-Russians in February 2014 (Interfaks 2014), passport recognition from Donetsk and Lugansk was something that the Russian government was reluctant to pursue before 2017 (Fischer 2016, 22-23). Teper (2016) has contrasted an 'unprecedented ethnicization of identity discourse' to frame the 'reunification' of Crimea with Russia with a 'predominantly utilitarian approach toward Russian ethno-nationalism' (380) in reference to the crisis in Eastern Ukraine. Despite the reference to the 'Russian world' in Putin's March 2014 speech to justify an irredentist policy on Crimea, Russia made no consistent attempt to reunite compatriots elsewhere with their 'homeland'.

This suggests that the Russian government was well aware of potential reputational costs, and that military adventures on foreign territory that is much more heterogeneous ethnically than Crimea would hardly be possible to justify. ${ }^{24}$ And even in ethnically more clear-cut cases, Putin's policy of denying political responsibility and investing heavily in PR activities to cover up a territorial annexation suggests that the Russian government knew that the argument of compatriot protection was highly controversial. Absent a solid legal legitimacy, Russia has justified its annexation of Crimea with a reliance on more emotive elements of diaspora conceptualisations (such as language, cultural, and historic links), combined with an invocation of threats from 'fascists'.

\section{Conclusion}


In an oft-quoted remark, Putin (2005) described the collapse of the Soviet Union as a 'major geopolitical disaster of the century'. This collapse suddenly left tens of millions of 'cocitizens and compatriots' outside the new borders of the Russian federation. Russian speakers were dislocated and deterritorialised. Following the legal doctrine of uti possidetis, new international borders now divided ethnoterritorial communities that previously had belonged to a larger biopolitical entity. The notion of Russia as a 'Divided Nation' (Laruelle 2015b), however, was mostly an academic hobby horse for much of the 1990s, and a cause for nationalists and revisionist intellectuals to critique the Russian government (Toal 2017, 7480). The Yeltsin government was slow to develop policies towards its 'compatriots' abroad, and was reluctant to encourage inward migration. The perception of compatriots slowly changed from being a liability (under Yeltsin) to being a potential foreign policy asset (under Putin). Research, however, has found that a sense of belonging to a language group is separate from political allegiances or a sense of belonging to a diaspora politically defined (Tishkov 2008, 32-33; Smith 1999; Smith and Wilson 1997; Kosmarskaya 2011; Kallas 2016, 15; King \& Melvin 2015, 115; Heleniak 2004, 114; Kolstø 2010; Toal 2017, 268-273). Such a finding suggests a weaker correlation between language - or even citizenship - and senses of 'national' belonging than assumed by the Russian government. There seems to be less willingness on the part of Russian 'diasporas' to be mobilized for political causes.

Against this background, this paper has shown how the conceptual difficulties of defining diasporas were reflected in the array of terminologies used in Russian governmental parlance. Defining compatriots in a broad sense, Russia began to develop institutional structures, agencies, and programmes to pursue policies aimed at the 'protection' of the rights of compatriots abroad, the support of their linguistic identity, and the promotion of their cultural ties with the Russian 'homeland'. Institutional consolidation from the mid-2000s onwards went hand in hand with a political rhetoric that made reference to a common civilizational space of a unified 'Russian World', of which the Russian language became a 
defining feature. The vision of a 'Russkiy Mir' became known to a wider international audience through the founding of the foundation with the same name, but the concept was much older and had been promoted by different political groups, academic circles, and the Russian Orthodox Church long before the Kremlin started to politicize the idea of a Russianspeaking world.

Lastly, this paper has traced how references to Russian diasporas became a politically useful tool to justify military policies to an international audience. The framing of the August 2008 war as a 'rescue' mission of co-ethnic communities was used as a storyline by the Russian government. Thereafter, the notion of a 'Russian World' has gained a politically inflammatory connotation that raises questions about contradictions in Russia's discourse on state sovereignty. The discourse to accompany direct military interference in Georgia in 2008, however, differed in nature from that accompanying Russia's interference in Ukraine in 2014. The argument that Russophones were under threat from a fascist junta in Kiev justified military intervention in Ukraine in 2014. Such a 'language factor', however, played a less prominent role in Georgia's breakaway provinces of Abkhazia and South Ossetia. Here, Russia referred to arguments about the need to protect co-ethnic Russians preceding the fiveday war with Georgia in 2008 following years of what critics have called a policy of 'passportisation' of these two de facto entities.

A lose application of the term 'compatriots' has served as a catch-all label to justify policies intended to 'protect' whoever classifies as a compatriot by Russian governmental definition (ethnic Russians, Russian-speakers, 'passportised' compatriots). In addition, eclectic arguments have been put forward to complement diaspora policies. The invocation of a threat ranged from references to an imminent genocide (in Georgia) to a fascist government in Ukraine. Thus, while the argument to protect Russian compatriots was employed on a rhetorical level, circumstantial factors in both cases differed and complicate an essentialist reading of Russian 'compatriot' policies as an instrument for territorial revisionism. The 
intended objective, it has been argued, was to explain the apparent contradictions in Russia's approaches to state sovereignty to an international audience. Geopolitical motivations like the prevention of Ukraine's and Georgia's integration into Western institutional structures were thus being couched in a language on human rights and 'humanitarianism', by which the Russian government mainly understands the protection of Russian minorities in neighbouring countries.

The analysis presented here has shown how a discrepancy between Russia's narrative projection about state sovereignty on an international level and breaches of the very same principle in its post-Soviet neighborhood were being smoothed out by 'compatriot' policies as a legitimizing factor. The instrumentalisation of identity politics as a discursive step to lay the groundwork for armed conflict became the means through which Russia justified controversial geopolitics to an international audience. Yet, as the conceptual evolution of Russia's diaspora politics shows, this has been an iterative process rather than a brainchild for revisionist policies from the outset.

\section{Notes}

\footnotetext{
${ }^{1}$ For a critique of the idea of Russian diaspora groups as sources for mobilisation in opposition to their host governments, see Lieven (1998, 243-268).

2 Russian protests over Estonian citizenship and residency requirements even led to a separatist referendum in the Northeastern Estonian cities of Narva and Sillamäe in 1993, which the Estonian State Council ruled illegal. ${ }^{3}$ See Grigas (2016) for a book-length analysis of how Russian compatriot policies have been used for what she calls 'neo-imperial aims' (3). Her work is based on the in-built assumption that Russian foreign policy is expansionist and is following a 're-imperialization policy trajectory' (10), making conclusions preconceived because the argumentation is essentialist. Policy stages discussed include soft power (stage 1), humanitarian policies (stage 2), compatriot policies (stage 3), passportization (stage 4), information warfare (stage 5), protection (stage 6), and annexation (stage 7) (29-56).

${ }^{4}$ Brubaker (2000) adds the category of 'accidental diasporas' that can form 'following a dramatic - and often traumatic - reconfiguration of political space' (2).

${ }^{5}$ In a discussion with the author, Sergei Karagnov stated that the doctrine was 'a mistake', and described the evolution of the 'doctrine' as the outcome of a last-minute request by the foreign ministry in which he was asked to give a seminar on the status of Russians abroad. The proceedings of that seminar, Karaganov explained, became the basis for the 'Karaganov doctrine'. Discussion with 'young leaders', including the author, at the Higher School of Economics, Moscow, 17 February 2017, organised by the PICREADI center.

${ }^{6}$ An Estonia foreign ministry official thus puts it in an interview: 'Russia feels they [Russian speakers in Estonia] are their compatriots, we feel they are our compatriots. The diaspora has been instrumentalised.' Author's interview, Tallinn, 7 June 2017.

${ }^{7}$ Author's interview, Tallinn, 7 June 2017.
} 
${ }^{8}$ At the same time, the Russian interior ministry has a programme for the encouragement of voluntary resettlement of Russians residing abroad. See Federal Law Nr. 77-F3 from 21 April 2011.

${ }^{9}$ In Estonia, for example, the 'Coordination Council of Russian Compatriots in Estonia' (Koordinatsionoj soviet rossijskikh sootechestvennikov Estonii) was set up in 2007 'under whose umbrella various compatriot organizations were united' (Kallas 2016, 10).

${ }^{10}$ See Rossotrudnichestvo's mission statement on their website: http://rs.gov.ru/ru/about.

${ }^{11}$ Or individuals that function as 'policy entrepreneurs' (Saari 2014, 59) like Moscow's former mayor Yuri Luzhkov, who has been active reaching out to Russian speakers in Russia's neighborhood, adopting programmes that promote legal, financial, or educational support for Russian compatriots (ibid.). The Moscow municipality, for example, established an International Council of Russian Compatriots (Laruelle 2015b, 91).

12 Tishkov (2008) importantly points out how the intellectuals promoting the 'Russian World' concept were to be seen in opposition to Dugin's idea of a 'Eurasian continental bloc' (7) that would also include countries like Iran and Turkey.

${ }^{13}$ The latter's influence is noticeable through references to the 'Holy Rus' within the 'Russian World' concept and Patriarch Kirill's repeated assertions that the 'Russian world' is a component of the Orthodox civilization (Kudors 2014). Yet, Bremer (2015) points out the paradoxical nature of the Orthodox Church's emphasis on the use of the Russian language, while Russian Orthodox masses are being held in Church Slavic (7).

${ }^{14}$ Other influential intellectuals that helped advance such an interpretation were Gleb Pavlovskiy, Sergey

Chernyshev, Yefim Ostrovskiy, and Maksim Shevchenko (Tishkov 2008, 4-5).

${ }^{15}$ Discussion with Prof. Sergey Markedonov, Associate Professor at Moscow State University, organised by the PICREADI center. Moscow, 18 February 2017. See also Gasimov 2012, 77.

${ }^{16}$ Author's interview, Tallinn, 7 June 2017.

${ }^{17}$ For studies on the 'weaponisation' of language, see Lecercle \& Riley 2005; Pratt 2009; Rafael 2012. The term has been used elsewhere to describe Russian policies on other policy front. Selective interpretations and the politicization of history have been read as a way to legitimize an increasingly anti-Western foreign policy from 2012 onwards. As Hill and Gaddy put it: 'From Putin's perspective, if the West was going to try to create fifth columns in Russia, then he was going to do the same in Europe. Social values, nationalism, religion, language, history - everything could and would become part of the battlefield' (352).

${ }^{18}$ In a discussion with the author, Sergey Markedonov stated that 'Passportisation' was an important policy to help non-recognised citizens in Abkhazia and South Ossetia. 'What were these people's options if they would encounter health problems, but Georgia wouldn't issue them passports and thus deny them access to social services and healthcare?', he asked. Discussion with Prof. Sergey Markedonov, Associate Professor at Moscow State University, organised by the PICREADI center. Moscow, 18 February 2017.

${ }^{19}$ Author's interviews and conversations with US, European, and Russian diplomats, former officials, and experts, 2011-2017.

${ }^{20}$ O'Loughlin and Toal (2015). write of an 'earned sovereignty' that Kosovo held due to its period of international administration. This differed in the South Ossetian, Abkhaz, and Crimean cases.

21 'Eurasian' intellectuals like Alexander Dugin and Alexander Prokhanov were instrumental in drumming up patriotic sentiments and mobilizing popular support, yet their direct influence on Kremlin is often exaggerated in the West (Laruelle 2015b, 90; 2017). See Clover (2016) for a book-length analysis of Dugin's instrumentality for official Kremlin positions on nationalism.

${ }^{22}$ Memorandum on Security Assurances in Connection to Ukraine's Accession to the Treaty on the NonProliferation of Nuclear Weapons, 19 December 1994. Available at [last accessed 22 May 2017]:

http://www.msz.gov.pl/en/p/wiedenobwe at $s$ en/news/memorandum on security assurances in connecti on with ukraine $s$ accession to the treaty on the npt?printMode=true.

${ }^{23}$ In August 2014, nationalist politicians Vladimir Zhirinovsky went one step further and even called on the Kremlin to annex Kazakhstan after the 'integration' of Crimea into the Russian Federation. See https://haqqin.az/news/29045.

${ }^{24}$ International tensions that the annexation of Crimea generated notwithstanding, the 'reunification' of Crimea with Russia, as it is called in Russia, enjoys a high level of legitimacy both within Crimea and in Russia (O'Loughlin and Toal 2015; O'Loughlin, Toal and Kolosov 2016). Southeastern Ukraine, apart from the fact that an annexation would be complicated logistically by the absence of clear boundaries, does not have the same historic-emotive significance (see also Tolz 2002). Russian nationalists have been disappointed by Kremlin policies in Eastern Ukraine (Kolstø 2016). 


\section{References}

Aasland, A. 1996. Russians outside Russia: The new Russian diaspora. In The nationalities question in the post-Soviet states, ed. G. Smith, G., 477-497. London: Longman.

Allison, R. 2008. Russia Resurgent? Moscow’s Campaign to "Coerce Georgia to Peace”, International Affairs 84 (6):1145-71.

Artman, V. 2013. Documenting Territory: Passportisation, Territory, and Exception in Abkhazia and South Ossetia. Geopolitics 18:682-704.

Armstrong, J. 1976. Mobilized and proletarian diasporas. American Political Science Review 70(2): 393-408.

Asmus, R. D. 2010. A Little War That Shook the World. New York: Palgrave Macmillan.

Derek, B. and Pedersen, R. B. 2013. Process Tracing Methods: Foundations and Guidelines. Michigan: University of Michigan Press.

Brah, A. 1996. Cartographies of Diasporas. Contesting Identities. London: Routledge.

Bremer, T. 2015. Die Russische Orthodoxe Kirche und das Konzept der „Russischen Welt““ Russland-Analysen 289, 30 January 2015:6-8.

Brubaker, R. 2000. Accidental diasporas and external 'homelands' in Central and Eastern Europe: Past and present. Institute for Advanced Studies, Vienna, vol. 71. Available at [last accessed 22 May 2017]: http://works.bepress.com/wrb/10/.

Brubaker, R. 2005. The 'diaspora' diaspora. Ethnic and Racial Studies 28(1):1-19.

Brüggemann, M. 2014. Zwischen Anlehnung an Russland und Eigenständigkeit: Zur Sprachpolitik in Belarus'. Europa ethnica 71 (3):88-94.

Büscher, K. 2016. Der Transnistrienkonflikt im Lichte der Krise um die Ukraine. In Nicht eingefroren! Die ungelösten Konflikte um Transnistrien, Abchasien, Südossetien und 
Berg-Karabach im Lichte der Krise um die Ukraine, ed. S. Fischer, 27-45. SWP Research paper, July 2016.

Chubais, A. 2003. Missiia Rossii v XXI veke (Russia's mission in the $21^{\text {st }}$ century). Nezavissimaia Gazeta, 1 October 2003. Accessed May 22, 2017. http://www.ng.ru/ideas/2003-10-01/1_mission.html.

Churkin, V. 2008. Letter Dated 11 August 2008 from the Permanent Representative of the Russian Federation to the United Nations Addressed to the President of the Security Council. Accessed January 18, 2018. http://www.securitycouncilreport.org/atf/cf/\%7B65BFCF9B-6D27-4E9C-8CD3CF6E4FF96FF9\%7D/Georgia\%20S\%202008\%20545.pdf.

Clover, C. 2017. Black Wind, White Snow. The Rise of Russia's New Nationalism. New Haven and London: Yale University Press.

Cohen, R. 1997. Global Diasporas. An Introduction. London: University College London Press.

Deyermond, R. 2016. The Uses of Sovereignty in Twenty-first Century Russian Foreign Policy. Europe-Asia Studies 68 (6):957-984.

Faist, T. 1998. Transnational social spaces out of international migration: evolution, significance, and future prospects. Arch. Europ. Sociol., 39 (2):213-47.

Fawn, R and R. Nalbandov. 2014. The difficulties of knowing the start of war in the information age: Russia, Georgia and the War over South Ossetia, August 2008. In Georgia: Revolution and War, ed. R. Fawn, 57-89. New York: Routledge.

Fischer, S. 2016. Die russische Politik in den ungelösten Konflikten. In Nicht eingefroren! Die ungelösten Konflikte um Transnistrien, Abchasien, Südossetien und Berg- 
Karabach im Lichte der Krise um die Ukraine, ed. S. Fischer, 9-26. SWP Research paper, July 2016.

Gaufman, L. 2015. Memory, Media and Securitization: Russian Media Framing of the Ukrainian Crisis. Journal of Soviet and Post-Soviet Politics and Society 1 (1):141174.

Gasimov, Z. 2012. Idee und Institution. Russkij Mir zwischen kultureller Mission und Geopolitik. Osteuropa 62 (5):69-80.

Geiss, R. 2015. Russia's Annexation of Crimea: The Mills of International Law Grind Slowly But They Do Grind. International Law Studies 91: 425-449.

Grant, T. D. 2015. Annexation of Crimea. American Journal of International Law 109 (1):6895.

Green, J. 2010. Passportization, Peacekeepers and Proportionality: The Russian Claim of the Protection of Nationals Abroad in Self-Defense. In Conflict in the Caucasus: Implications for International Legal Order, ed. J. Green and C. Waters, 54-79. New York: Palgrave Macmillan.

Grigas, A. 2016. Beyond Crimea. The New Russian Empire. New Haven and London: Yale University Press.

Hedenskog, J and R. L. Larsson. 2007. Russian Leverage on the CIS and the Baltic States. Defense Analysis. Swedish Defense Research Agency (FOI).

Heleniak, T. 2004. Migration of the Russian Diaspora after the Breakup of the Soviet Union. Journal of International Affairs 57 (2): 99-117.

Hill, F and C. G. Gaddy. 2013. Mr. Putin. Operative in the Kremlin. Washington: Brookings Institution Press. 
Hill, F and C. G. Gaddy. 2015. What makes Putin tick, and what the West should do. Brookings Report, 13 January 2017. Accessed February 22, 2018. https://www.brookings.edu/research/what-makes-putin-tick-and-what-the-westshould-do/.

Independent International Fact-Finding Mission on the Conflict in Georgia (IIFFMCG). 2009. Report, vol. II, September 2009. Accessed March 16, 2017. http://www.mpil.de/files/pdf4/IIFFMCG_Volume_II1.pdf.

Inozemtsev, V. 2017. Vernarrt in die Vergangenheit. Internationale Politik, January/February 2017: 74-83.

Interfaks. 2014. Dlia zhitelei SNG uprostiat protseduru polucheniia rossiiskogo grazhdanstva (Russian naturalisation process simplified for citizens of CIS countries), Interfaks, 27 February 2014. Accessed March 22, 2017. http://www.interfax.ru/russia/361446.

International Crisis Group. 2011. Georgia-Russia: Learn to Live like Neighbours. Europe \& Central Asia Briefing Nr. 65. Accessed March 22, 2017. https://www.crisisgroup.org/europe-central-asia/caucasus/georgia/georgia-russialearn-live-neighbours.

Jilge, W. 2014. Analyse: Die Ukraine aus Sicht der "Russkij Mir". Bundeszentrale für politische Bildung, 17 June 2014. Accessed March 21, 2017. http://www.bpb.de/internationales/europa/russland/186517/analyse-die-ukraine-aussicht-der-russkij-mir.

Kallas, K. 2016. Claiming the diaspora: Russia's compatriot policy and its reception by Estonian-Russian population. Journal on Ethnopolitics and Minority Issues in Europe 15 (3):1-25. 
Karagiannis, E. 2014. The Russian Interventions in South Ossetia and Crimea Compared: Military Performance, Legitimacy and Goals. Contemporary Security Policy 35 (3):400-420.

King, C. 1998. Introduction: Nationalism, transnationalism, and post-communism. In Nations abroad. Diaspora politics and international relations in the former Soviet Union, ed. C. King and N. J. Melvin, 1-25. Boulder, CO: Westview Press.

King, C. and N. J. Melvin. 1999/2000. Diaspora Politics. Ethnic Linkages, Foreign Policy, and Security in Eurasia. International Security 24 (3):108-138.

Kolst $\varnothing$, P. 1993. The new Russian diaspora: Minority protection in the Soviet successor states. Journal of Peace Research 30: 197-217.

Kolstø, P. 1995. Russians in the Former Soviet Republics. London: Hurst \& Company.

Kolst $\varnothing$, P. 2001. 'Russian Diasporas in the 'Near Abroad': Implications for International Peace. Diaspora: A Journal of Transnational Studies 10 (2):297-305.

Kolstø, P. 2010. The new Russian diaspora - an identity of its own? Possible identity trajectories for Russians in the former Soviet republic. Ethnic and Racial Studies 19 (3):609-639

Kolstø, P. 2016. Crimea vs. Donbas: How Putin Won Russian Nationalist Support—and Lost it Again. Slavic Review 75 (3):702-25.

Korts, K. 2009. Inter-Ethnic Attitudes and Contacts between Ethnic Groups in Estonia. Journal of Baltic Studies 40 (1):121-137.

Kosmarskaya, N. 2011. Russia and Post-Soviet 'Russian Diaspora': Contrasting Visions, Conflicting Projects. Nationalism and Ethnic Politics 17 (1):54-74.

Krasner, S. 1999. Sovereignty. Organized Hypocrisy. Princeton: Princeton University Press. 
Kremlin. 2008. The Foreign Policy Concept of the Russian Federation. 12 January 2008. Accessed June 22, 2017. http://en.kremlin.ru/supplement/4116.

Kudors, A. 2014. The 'Russian world' as a vacuum cleaner. Baltic Scholars for Ukraine, Post, 24 April 2014. Accessed March 22, 2017. https://balticscholars.stanford.edu/?p=805.

Kureev, A. 2015. Russian Diaspora: A tool of soft power? Russia Direct, 11 November 2015. Accessed March 28, 2017. http://www.russia-direct.org/opinion/russian-diasporatool-soft-power.

Laitin, D. D. 1995. Identity in Formation: The Russian-Speaking Nationality in the PostSoviet Diaspora. Archives européennes de sociologies 36 (2):281-316.

Laruelle, M. 2015a. The Three Colors of Novorossiya, or the Russian Nationalist Mythmaking of the Ukrainian Crisis. Post-Soviet Affairs 32 (1):55-74.

Laruelle, M. 2015b. Russia as a 'Divided Nation,' from Compatriots to Crimea: A Contribution to the Discussion on Nationalism and Foreign Policy. Problems of PostCommunism 62 (2):88-97.

Laruelle, M. 2017. In search of Putin's philosopher. Intersection, 3 March 2017. Accessed May 16, 2017. http://intersectionproject.eu/article/politics/search-putins-philosopher.

Lauristin, M and M. Heidmets (eds.) 2003. The Challenge of Russian Minority: Emerging Multiculturalism in Estonia. Tartu: Tartu University Press.

Lavrov, S. 2014. Interview of the Russian Foreign Minister Sergey Lavrov to "Bloomberg TV”, Moscow, 14th of May 2014. Accessed October 21, 2017. http://www.mid.ru/en/web/guest/maps/ua//asset_publisher/ktn0ZLTvbbS3/content/id/60498.

Lavrov, S. 2015. Foreign Minister Sergey Lavrov's live radio interview with Sputnik, Ekho Moskvy and Govorit Moskva, Moscow, April 22, 2015. Accessed October 21, 2017. 
http://www.mid.ru/en/web/guest/foreign_policy/news//asset_publisher/cKNonkJE02Bw/content/id/1199312.

Lecercle, J.-L. and D. Riley. 2005. The Force of Language. Houndmills: Palgrave Macmillan. Lieven, A. 1998. Chechnya: Tombstone of Russian Power. New Haven, Connecticut: Yale University Press.

Littlefield, S. 2009. Citizenship, Identity and Foreign Policy: the Contradictions and Consequences of Russia's Passport Distribution in the Separatist Regions of Georgia. Europe-Asia Studies 61 (8):1461-1482.

Mackinnon, M. 2014. Sergey Karaganov: The man behind Putin's pugnacity. The Globe and Mail, 30 March 2014. Accessed February 02, 2017. http://www.theglobeandmail.com/news/world/sergey-karaganov-the-man-behindputins-pugnacity/article17734125/.

Mathyl, M. 2002. Der „unaufhaltsame Aufstieg“ des Aleksandr Dugin. NeoNationalbolschewismus und Neue Rechte in Russland. Osteuropa 7:885-900.

Medvedev, D. 2008a. Dimitry Medvedev Made a Statement on the Situation in South Ossetia. Kremlin Transcript, 8 August 2008. Accessed February 22, 2018. http://en.kremlin.ru/events/president/news/1043.

Medvedev, D. 2008b. Press Statement following Negotiations with French President Nicolas Sarkozy. Kremlin transcript, 12 August 2008. Accessed October 26, 2017. http://en.kremlin.ru/events/president/transcripts/1072.

Melvin, N. 1995. Russians Beyond Russia. The Politics of National Identity. London: Bloomsbury. 
Melvin, N. 1998. The Russians: Diaspora and the End of Empire. In Nations Abroad: Diaspora Politics and International Relations in the Former Soviet Union, ed. C. King and N. J. Melvin, 27-57. Boulder, CO: Westview Press.

Miskimmon, A, B. O’Loughlin; and L. Roselle. 2013. Strategic Narratives. Communication power and the new World Order. London and New York: Routledge.

Moore, W. H. and D. R. Davis. 1998. Transnational Ethnic Ties and Foreign Policy. In The International Spread of Ethnic Conflict: Fear, Diffusion, and Escalation, ed. D. A. Lake and D. Rothchild, 89-104. Princeton: Princeton University Press.

Mühlfried, F. 2010. Citizenship at War: Passports and Nationality in the 2008 RussianGeorgian Conflict. Anthropology Today 26 (2):8-13.

O’Loughlin, J. and G. Toal. 2015. The Crimean conundrum. OpenDemocracy, 3 March 2015. O’Loughlin, J., G. Toal and V. Kolosov. 2016. Who identifies with the 'Russian World'? Geopolitical attitudes in southeastern Ukraine, Crimea, Abkhazia, South Ossetia, and Transnistria. Eurasian Geography and Economics 57 (6):745-778.

O’Loughlin, J., G. Toal and V. Kolosov. 2017. The Rise and Fall of 'Novorosskiya': Examining Support for a Separatist Geopolitical Imaginary in Southeastern Ukraine. Post-Soviet Affairs 33: 124-144.

OSCE. 2008. OSCE High Commissioner on National Minorities, The Bolzano/Bozen Recommendations on National Minorities in Inter-State Relations \& Explanatory Note, The Hague, June 2008. Accessed March 16, 2017. http://www.osce.org/hcnm/33633?download=true.

Petersen, A. 2017. Eurasia's Shifting Geopolitical Tectonic Plates. Global Perspective, Local Theaters. Lanham, MD: Lexington Books. 
Petro, N. N. 2015. Russia’s Orthodox Soft Power. Carnegie Council, 23 March 2015. Accessed March 22, 2017. http://www.carnegiecouncil.org/publications/articles_papers_reports/727.

Pilkington, H.A. and M. B. Flynn. 2001. Chuzhiye na rodine? Issledovaniye "diasporal'noi identichnosti” vynuzhdennykh pereselentsev. Diasporas 3 (2):8-34.

Pratt, M. 2009. Harm's Way: Language and the Contemporary Arts of War. PMLA 124 (5):1515-1531

Putin, V. 2005. Poslanie Federal'nomu Sobraniiu Rossiiskoi Federatsii (Address to the Federal Assembly of the Russian Federation), 25 April 2005. Accessed May 23, 2017. http://kremlin.ru/events/president/transcripts/22931.

Putin, V. 2006. Transcript of the Press Conference for the Russian and Foreign Media, 31 January 2006. Accessed October 24, 2017. http://en.kremlin.ru/events/president/transcripts/23412.

Putin, V. 2014a. Obrashchenie Prezidenta Rossiiskoi Federatsii (Address by President of the Russian Federation), 18 March 2014. Accessed March 22, 2017. http://kremlin.ru/events/president/news/20603.

Putin, V. 2014b. Priamaia liniia s Vladimirom Putinym (Direct Line with Vladimir Putin). 17 April 2014. Accessed March 22, 2017. http://kremlin.ru/events/president/news/20796.

Rafael, V. 2012. Targeting Translation: Counterinsurgency and the Weaponization of Language. Social Text 30 (4):55-80.

Russian foreign ministry. 2006. Zakonodatel'stvo Rossiiskoi Federatsii. Normativnye pravovye akty (Legislation of the Russian Federation. Normative legal acts), 22 November 2006. Accessed October 5, 2017. 
http://www.mid.ru/activity/compatriots/zakon/-

/asset_publisher/kQVwXqXaMW7q/content/id/387000.

Russian foreign ministry. 2008. Otvety stats-sekretaria - zamestitelia ministra inostrannykh del rossii g.b.karasina na voprosy informatsionnogo agentstva 'interfaks' (Response by Russian Deputy Minister of Foreign Affairs/State Secretary Grigory Karasin to Questions from Interfax News Agency), 13 August 2008. Accessed October 21, 2017. http://www.mid.ru/web/guest/foreign_policy/international_safety/conflicts//asset_publisher/xIEMTQ3OvzcA/content/id/328286.

Russian foreign ministry. 2017. Programma: raboty s sootechestvennikami, prozhivaiushchimi za rubezhom, na 2015 - 2017 gody (Programme: Work with compatriots living abroad for the years 2015-2017), Government of the Russian Federation, Directive No 2321, Moscow, 19 November 2014. Accessed October 5, 2017.

http://www.mid.ru/documents/10180/822665/\%D0\%A0\%D0\%9F\%20\%D0\%9F\%D 1\%80\%D0\%B0\%D0\%B2\%D0\%B8\%D1\%82\%D0\%B5\%D0\%BB\%D1\%8C\%D1\%8 1\%D1\%82\%D0\%B2\%D0\%B0\%202321\%D1\%80\%20\%D0\%BE\%D1\%82\%2019+\%D0\%BD\%D0\%BE\%D1\%8F\%D0\%B1 \%D1\%80\%D1\%8F\%202014+\%D0\%B3.+\%D0\%B8\%20\%D0\%9F\%D1\%80\%D0\% BE\%D0\%B3\%D1\%80\%D0\%B0\%D0\%BC\%D0\%BC\%D0\%B0\%20\%D0\%BD\%D0 \%B0\%2014-15+\%D0\%B3\%D0\%BE\%D0\%B4\%D1\%8B.pdf/f2651998-2ac3-4266b9b4-c55592a00990.

Russkiy Mir. 2017. Mission statement. Accessed March 21, 2017. http://russkiymir.ru/fund/. Ryazanova-Clarke, L. 2014. Russian with an Accent: Globalisation and the Post-Soviet Imaginary. In The Russian Language Outside the Nation, ed. L. Ryazanova-Clarke, 359-409. Edinburgh: Edinburgh University Press. 
Ryazanova-Clarke, L. 2015. From commodification to weaponization: the Russian language as 'pride' and 'profit' in Russia's transnational discourse. International Journal of Bilingual Education and Bilingualism, 26 December 2015: 1-14.

Saari, S. 2014. Russia's Post-Orange Revolution Strategies to Increase its Influence in Former Soviet Republics: Public Diplomacy po russkii. Europe-Asia Studies 66 (1):50-66.

Safran, W. 1991. Diasporas in modern societies: Myths of homeland and return. Diaspora: A journal of transnational studies 1: 83-99.

Sakwa, R. 2017. Russia against the Rest. The Post-Cold War Crisis of World Order. Cambridge: Cambridge University Press.

Shchedrovitskii, P. 2000. Kto I schto stoit za doctrinoi Russkogo mira? (Who and What is Behind the Doctrine of the Russian World?) Russkii Archipelag. Accessed October 3, 2017. http://www.archipelag.ru/ru_mir/history/history99-00/shedrovicky-doctrina/.

Shevel, O. 2012. The Politics of Citizenship Policy in Post-Soviet Russia. Post-Soviet Affairs $28(1): 111-147$.

Sherr, J. 2013. Hard Diplomacy and Soft Coercion: Russia's Influence Abroad. London: Royal Institute of International Affairs.

Simonsen, S. G. 2001. Compatriot games: Explaining the 'diaspora linkage' in Russia's military withdrawal from the Baltic states. Europe-Asia Studies 53: 771-791.

Smith, D. J., A. Pabriks, A. Purs and T. Lane. 2002. The Baltic States. Estonia, Latvia and Lithuania. London and New York: Routledge.

Smith, G. 1999. Transnational politics and the politics of the Russian diaspora. Ethnic and Racial Studies 22 (3):500-523. 
Smith, G and A. Wilson. 1997. Rethinking Russia's post-Soviet diaspora: the potential for political mobilization in eastern Ukraine and north-east Estonia. Europe-Asia Studies $49(5): 845-64$.

Stent, A. E. 2014. The Limits of Partnership. U.S.-Russian Relations in the twenty-first century. Princeton and Oxford: Princeton University Press.

Stewart, S. 2017. Grundeinstellungen der russischen politischen Elite. Recht, Wahrheit, Gemeinwohl und Gewalt. SWP Research Paper Nr. 5, March 2017. Accessed March 22, 2017. https://www.swp-berlin.org/publikation/grundeinstellungen-derrussischen-politischen-elite/.

Suslov, M. 2018. "Russian World” Concept: Post-Soviet Geopolitical Ideology and the Logic of "Spheres of Influence” Geopolitics, 25 January 2018: 1-24.

Teper, Y. 2016. Official Russian identity discourse in light of the annexation of Crimea: national or imperial? Post-Soviet Affairs 32 (4):378-396.

Tishkov, V. 2008. The Russian World - Changing Meanings and Strategies. Russia and Eurasia Program Nr. 95, August 2008. Carnegie Endowment for International Peace.

Toal, G. 2017. Near Abroad: Putin, the West and the Contest for Ukraine and the Caucasus. New York: Oxford University Press.

Tolz, V. 2002. Rethinking Russian-Ukrainian relations: A New Trend in Nation-building in Post-communist Russia? Nations and Nationalism 8 (2):235-253.

Tölöyan, K. 1996. Rethinking diaspora(s): stateless power in the transnational moment. Diaspora 5 (1):3-36. 
United Nations Security Council. 2008. 5953 ${ }^{\text {rd }}$ meeting, 10 August 2008. S/PV.5953, Accessed October 26, 2017. http://www.un.org/en/ga/search/view_doc.asp?symbol=S/PV.5953.

Wiener, A. 2009. Enacting meaning-in-use: qualitative research on norms and international relations. Review of International Studies 35: 175-193.

Zabirko, O. 2015. 'Russkij Mir'. Literarische Genealogie eines folgenreichen Konzepts. Russland-Analysen nr. 289, 30 January 2015: 2-5.

Zevelev, I. 1996. Russia and the Russian Diasporas. Post-Soviet Affairs 12 (3):265-284.

Zevelev, I. 2001. Russia and Its New Diasporas. Washington, DC: United States Institute of Peace.

Zevelev, I. 2014. The Russian World Boundaries: Russia’s National Identity Transformation and New Foreign Policy Doctrine. Russia in Global Affairs, no. 2. Accessed October 3, 2017. http://eng.globalaffairs.ru/number/The-Russian-World-Boundaries-16707.

Zhurzhenko, T. 2014. A Divided Nation? Reconsidering the Role of Identity Politics in the Ukraine Crisis. Die Friedenswarte 89 (1):249-267.

Ziegler, C. E. 2006. The Russian Diaspora in Central Asia: Russian Compatriots and Moscow's Foreign Policy. Demokratizatsiya 14 (1):103-126. 